\title{
Expat-Friendly Public Policy for Istanbul: From Discourse to Action
}

\author{
Recep BOZLAĞAN ${ }^{*}$ \\ Nail YILMAZ ${ }^{* *}$ \\ Murat DAOUDOV ${ }^{* * *}$ \\ Lauranne CALLET-RAVAT ${ }^{* * * *}$
}

\begin{abstract}
In the developed countries there is a growing discourse about attracting human capital as one of the key tools to strengthen the economic competitiveness. This phenomenon is also visible at local level, notably through increasing focus on city branding and emphasis on attraction of talents and investors, and increased involvement of local/regional governments in this field. Turkey also steadily adopts similar discourse in its policy documents such as the national and local plans and strategy papers; these documents emphasize the goal of becoming "center of attraction" and gaining qualified labor force. Istanbul plays an important role as a major experimentation site for the success of such policy. In this framework Turkey transforms and modernizes its migration policy, and the officials call for various policies and practices that would create favorable living and working conditions for foreigners or expats. However this approach is not yet translated into concrete actions that would have tangible impact on public sector policies and institutions in Istanbul, whether central or local/metropolitan government units, and that would be visible to the expats themselves. The analysis of the findings of the survey realized by the authors in order to measure the perception of public services in Istanbul by the expats, combined with other resources, suggests that, despite the higher level discourse, public institutions lack concrete policies on the ground. The article therefore formulates several recommendations to raise the awareness of decision-makers and to develop expat-friendly public policy in Istanbul.
\end{abstract}

Keywords: Expat, Qualified Labor Migration, Attraction of Human Capital, Migration Policy, Harmonization, Integration Policy, Expat-Friendly Public Policy.

* Prof. Dr., Department of Public Administration, Faculty of Political Science, Marmara University, E-mail: recepbozlagan@gmail.com

** Assoc. Prof. Dr., Department of Public Administration, Faculty of Political Science, Marmara University, E-mail: yilmaznail@hotmail.com

*** Department of Public Administration, Faculty of Political Science, Marmara University, E-mail: murat.daoudov@ gmail.com

**** Researcher, Middle East Development Network (MDN), E-mail: lauranne.calletravat@sciencespo.fr 


\title{
İstanbul İçin Expat-Dostu Kamu Politikası: Söylemden Eyleme Geçme Zamanı
}

\begin{abstract}
Özet
Gelişmiş ülkelerde, ekonomik rekabet edebilirliğin güçlendirilmesi için kilit öneme sahip sayılan araçlar içerisinde, kaliteli insan gücünün çekilmesi söylemi giderek yükselmektedir. Bu olgu bilhassa şehir markacılığı ile yetenekleri ve yatırımcıları çekme konularına yapılan vurgular şeklinde yerel düzeyde de görünür hale gelmekte, yerel/bölgesel yönetimler de artık bu alanda daha fazla aktif olmaktadır. Türkiye de artan ölçüde bu söylemi, ulusal ve yerel planlar gibi siyaset belgelerinde benimsemekte; "çekim merkezi” olma ve vasıflı iş günücü çekme hedefini vurgulamaktadır. Bu politikanın başarısı için İstanbul kilit uygulama alanı olarak önemli rol oynamaktadır. Bu çerçevede Türkiye göç politikasını dönüştürmekte ve modernleştirmekte, ve yabancıların veya expatların hayat ve çalışması için uygun şartları oluşturacak çeşitli politika ve uygulamalara olan ihtiyacı açıç̧a dile getirmektedir. Ancak bu yaklaşım, ister merkezî ister yerel/metropoliten yönetim düzeyinde olsun, kamu kurumları veya kamu sektörü potikaları üzerinde etki yapacak oranda ve expatlar için görünür olacak şekilde eylemlere henüz dönüştürülememiştir. İstanbul'da kamu hizmetleri hakkında expatların algısını ölçmeye yönelik yazarlarca gerçekleştirilen anketin çıktılarının analizi ile diğer kaynaklar ışığında yapılan değerlendirmeler, üst seviyedeki söyleme rağmen, bu alanda kamu kurumlarının somut politikalarının sahada eksik olduğu kanaatini oluşturmaktadır. Binaenaleyh makale, expat-dostu kamu politikasını geliştirmeye yönelik bazı tavsiyeleri sunmaktadır.
\end{abstract}

Anahtar kelimeler: Expat, Vasıflı İş Göçü, İnsan Kaynağını Çekme, Göç Politikası, Uyum Politikası, Expat-Dostu Kamu Politikası.

\section{Introduction}

Several concomitant factors in the recent decade raises Istanbul's attractiveness for the expats. This development is result of several push and pull factors. The rapid economic development of Turkey in the recent decade, the increased connectedness with the global economy, major strategies and policy orientations of the Turkish Government like, for example, the decision to make Istanbul an international financial center can be seen as major pull factors. In addition, specific factors result from the well-rooted attractiveness of Istanbul, the city which enjoys unique character in terms of history and geographic position, combined with its modern-style advantages of well-connected means of transports and communications, liberal visa regime etc. Turkish national and local policy makers are increasingly eager to present Istanbul as the "world's privileged meeting point" and Turkey as "a privileged place to live for expatriates and their families". In parallel Turkey develops a new migration policy that seeks to benefit from qualified human capital. Some push factors also concurrently add up to the pull factors mentioned, such as the economic stagnation in the neighboring Europe, and various political instabilities in the near 
Asia or North Africa, that drive to Istanbul diverse populations, from young graduates in quest of better opportunities (Pérouse, 2012: 10; 2013: 92), to businessmen in need of "stable ports" for their investments, to political activists or refugees.

There is an expanding international literature about the phenomenon of the expats, on their social, cultural and economic characteristics, and the relationship between the concepts of "expat" and "migrant". Much is said and written about the expats and their trajectories, choice of destination, individual or group behavior. From a different perspective, the study aims to approach the expat phenomenon in Istanbul from public policy point of view, in the light of the policy developments which are described in detail in the following parts. The study seeks to understand whether the expats are the subject of public policy and the target audience of public services, and if so, to which extent the administration has translated this into concrete actions, while also measuring their impact on the expat community in Istanbul.

\section{The Rationale and the Methodology}

The idea in the core of the study lies at the intersection of the fields of migration, public policy, and administration (central and local). The composition of the research team that consists of both expats and public policy professionals has naturally nourished their interest in this subject. The present study is a result of a rather long process. ${ }^{1}$ It was observed that there is a need to study the expectations of the expats in Istanbul and to identify the policies that focus or have impact on them. This observation had led an initial attempt, in 2011, to launch a questionnaire titled "Study on the Socio-Economic and Cultural Situation of Highly Qualified Foreign Professionals (Expats) Working/Living in Istanbul and their Assessment of the Public and Private Sector Service-Provision in the City". The research was launched under the umbrella of Union of Municipalities of Marmara (UMM) and Marmara University's Department of Istanbul Studies. ${ }^{2}$ The initial attempt took the form of a questionnaire in Word format distributed by email and fax among various expat associations, through mailing lists and personal contacts and so on. However the questionnaire found little echo in terms of responses. The second attempt was launched in early 2013 again in the form of a Word questionnaire attached to emails. Despite the efforts, the results of the second attempt were not sufficient enough as desired. The issue of securing the participation of the expats in the survey appeared as a challenge to the study. ${ }^{3}$

1 The initial discussion took place in early 2010 in the Union of Municipalities of Marmara (UMM) between Nail Yilmaz, then adviser of the Union and lecturer in urban sociology at Marmara University (MU), and Murat Daoudov, then director of international cooperation of the Union (Belgian citizen resident in Istanbul).

2 The research team was joined by Recep Bozlagan, then secretary general of UMM and head of Istanbul Studies Dept. of $\mathrm{MU}$, and lecturer specialized in local government and global city matters.

3 This initiative has achieved its objectives thanks to the benevolent involvement of other expats. Thus one of email respondents, Sophie Ar1, French citizen resident in Istanbul, gave a critical advice of transforming the questionnaire into an online survey easier to use for both users and researchers, and brought valuable support in improving the questionnaire’s content. 
After the revision of the strategy, an open online questionnaire had been designed and launched on SurveyMonkey.com. Using this online survey software allowed the researchers to reach the number of 100 respondents that corresponded to the expat profile criteria as set by the team, between February 2013 and November 2014. ${ }^{4}$

The online questionnaire consisted of 64 questions (47 of 67 are "multiples choice questions") divided into 8 sections: 1. Personal information (20 questions), 2. Overall opinion about Turkey and Istanbul (6 q.), 3. Opinion about social and cultural issues (9 q.), 4. Opinion on associations and services by civil society ( 6 q.), 5. Opinion on services provided by private sector (2 q.), 6. Opinion on services provided by central government authorities (8 q.), 7. Opinion on services of local authorities/ municipalities (9 q.), 8. Final remarks (4 q.).

The survey remained open up until the number of 100 respondents who matched the expat profile criteria was reached, and some 40 profiles were eliminated. The elimination concerned the following types of respondents: 1) People of Turkish nationality that moved back to Turkey (can be considered as descendants of Turkish immigrants); 2) Those who live in Istanbul for considerably long period (some of respondents lived in Istanbul for more than 20 years); 3) Those who don't reside or not reside anymore in Istanbul; 4) Those that left the questionnaire to great extent incomplete.

The limitations of this study can be summarized in two groups, the ones related with the questionnaire's process and others related with the constraints of the present publication. In relation with the process, the questionnaire had undergone certain minor structural changes while converting Word questionnaire to online survey. Only the answers given to the online survey have been taken into account in the analysis, while some limited number of respondents that had returned the Word questionnaire by email or fax has not been considered. ${ }^{5}$ The length of the questionnaires (64 questions) has also caused critics from the respondents. This may be the reason of incomplete participation when some respondents gave up after initial efforts. As to the limits of the current study, only some key findings have been focused on. In consequence, other areas of potential interest, notably the socio-economic profile of expats and its correlation with their social and cultural behavior, as well as other elements require further work. ${ }^{6}$

4 In this stage the team was joined by another expat and professional, Lauranne Callet-Ravat, French citizen, master graduate from Sciences-Po Paris in metropolitan governance. Callet-Ravat works as researcher and business development manager at Middle East Development Network (MDN), public policy consulting firm specialized in local government and migration matters. In this configuration the team advantageously blended personal experiences of "expats" and professional and academic expertise in local government and migration.

5 Although, it is likely that some of them participated a second time in the online survey format, which had been sent to all previous respondents.

6 The first findings of the survey have been shared by Nail Yilmaz and Murat Daoudov in the "Workshop on Migration Management and Harmonization in the Framework of the Law No 6458 on Foreigners and International Protection", organized by General Directorate of Migration Management of Turkish Ministry of Interior and International Organization for Migration (IOM), with the support of Kingdom of the Netherlands, held in Ankara on 12 December 2013. 


\section{The Concept of the Expat}

An expatriate (often shortened to expat) is a person temporarily or permanently residing in a country other than that of his/her citizenship. The word comes from the Latin terms ex ("out of") and patria ("country, fatherland"). In common usage, the term is often used in the context of professionals or skilled workers sent abroad by their companies (Castree, Kitchen, Rogers, 2013). According to Green (2009: 307), the terms "expatriate" and "expatriation" have a long and complex history. Their use ranges from simple residence abroad ("for a considerable amount of time") to the more definitive legal renunciation or destitution of allegiance, "denationalization or "decitizenization". By the mid-1960s, a new figure of the leave-taker emerged, that of the globalized expat, and increased mobility has given new meaning to the concept of citizens abroad. By the latter part of the twentieth century in business circles, "expat" is most often used to designate someone sent abroad to represent a multinational firm. The expat's status is generally a privileged one. (Green, 2009: 322-323) It contrasts with "immigrant worker" or "gastarbeiter".

The term "expat" is usually used to designate highly skilled migrants or short-term professional migrants. The similarity and difference between migrant/immigrant and expat has been subject of many discussions (see Nagel, 2005). The common distinction between the two can be summarized as follows: the expat is often citizen of the developed countries (the Global North), a highly qualified worker or artist that moves to other countries for the sake of the advancement of his professional career, or for acquiring additional set of sophisticated qualifications, often in the trajectory within or along multinational companies or organizations. In contrast, the "immigrants" or "labor migrants" are generally considered to come from the Global South, to have lower socio-economic situation and to possess less sophisticated educational background and level of skills. To simplify, the "rich expat" is the opposite of the "poor immigrant", the first being welcome and the second rather undesired. Gatti (2009) explains that expats seem to represent a sort of "positive" immigration, in contrast with the "negative" traditional immigration, whereas according to Daoudov (2013), from the public-political point of view, there is an immigration borne or tolerated (katlanılan göç) and there is immigration desired (arzu edilen göç). ${ }^{7}$ This latter refers notably to the "expats" that public actors are eager to attract to their cities or countries. ${ }^{8}$

In terms of the scope, the definition of the term of expat can be done through two approaches, the narrow and the broader one. The narrow scope uses the term of "intra-company transfer" (ICT) and defines expat as a professional that moves to a new country in the framework of his work, to

7 Although similar discourse in public sphere appears in many countries, the dichotomy of "endured/suffered immigration" and "selected/chosen immigration" (immigration subie / immigration choisie) appeared in 2003-2006 in France in the framework of the reform of the law on foreigners (Lochak, 2006).

8 During the press conference of the Preferential Transformation Program under the 10th Development Plan which revealed new economic plan to boost the economy, Turkish Prime Minister Ahmet Davutoglu declared that the package aimed at making Turkey "the center of attraction for qualified foreign labor force", and said that the special measures will be taken to "guarantee immigration to Turkey of most qualified human resources", "people whose coming is especially desired". Video record of the conference at http://www.haberler.com/yapisal-donusum-10kalkinma-plani-6912118-haberi/. 
fulfil new tasks or occupy new position in a different work-site within a multi-national company or similar entity. He/she subsequently is posted for rather a limited time and later moves further to another station within the same institutional trajectory. The lifetime of expats in a given place, according to this definition, is usually limited to several years, and some authors limit it to 3 to 5 years (Gatti, 2009).

The broad definition includes broader range of professionals or artistes that migrate to new country or city (often an international or global city), as result of their personal choice, for the sake of a new job or activity, most often for a new employer or in order to start their own business, academicians, as well as other types (Nagel, 2005; Gatti 2009; Pérouse, 2012). These expats share some characteristics with the "ICT expats" in that they are often considered to belong to the Global North, have good educational background and rich professional experience, and have or can afford a life standard above the average in the new country. This broad definition is adopted in the present work, which is also reflected in the title of the questionnaire used (Highly Qualified Foreign Professionals (Expats)).

\section{Relation Between Expats and Public Policies}

The concept of the expat is often also related with the concept of international or global city. International or global cities are major destinations of expat movements because they are considered as places with high concentration of economic opportunities, targets for foreign investments, places of intense cultural and artistic activities. The concentration of expats impacts positively city's ranking among its peers. For example, the Global Power City Index (GPCI 2009: 10) takes into account the attractiveness of the city to the "global actors" that lead urban activities such as managers, researchers, artists, and visitors. The Global Cities Index and Emerging Cities Outlook stresses the importance of the cities' capacity to attract and to retain the global flow of ideas, capital and people, for the their success in rating and their ability to rise in power and influence (A.T. Kearney Global Cities Outlook, 2012:5). According to Gatti (2009), also more and more attention is given by sociologists to the relation between cities, development and the activities and profiles of the people attracted by cities themselves. She refers to Harvey (1990) in that cities are in open competition to attract investments and people - not all kinds of people, of course, but tourists, investors and high-skilled professionals.

There are several fields where intersection occurs between and the public administration and policy. The primary example is the field of policies aiming at attracting foreign direct investments and businesses. These policies have direct impact on attracting businessmen and qualified labor force. Along the national government level efforts, the efforts aiming at bringing investment and increasing the interest for the city or region are also increasingly on the agenda of local/regional 
governments and regional development agencies. ${ }^{9}$ Calay (2007) speaks of the emerging "policy of attractiveness" at the level of city, in the case of the "capitals of Europe" that are Brussels, Strasbourg and Luxembourg. He develops an analysis, based on the works of several authors, which points at the phenomenon of metropolization in the post-fordist urban economies. Thus the "attractiveness" is now added to the strategic development plans of cities; the process of metropolization stimulates the focus on local/urban level in the policy making. This in turn strengthens the role of the local governments in urban management policies. The international dimension of this "attractiveness" policy includes the development of tourism and of foreign direct investments.

The second intersection point is the policies of integration of migrants which are designed on national and, increasingly, on sub-national level. Thus since two or three decades, in Europe and in the developed countries, there is a growing consensus that, on one side, urban spaces are key scales for the integration of immigrants, and, on the other side, that the local and regional governments are key actors in promoting and achieving successful integration policy. Since late 1980's the Council of Europe adopted a number of recommendations and resolutions that emphasize the role of local and regional governments in the matters related with social, cultural, economic and political integration of migrants (Daoudov, 2014). This progress in regionalization or localization of integration policies can be observed in the growing emphasize on local/regional level when comparing two similar documents on "Integration of Third-Country Nationals" adopted by the European Union in 2005 and in 2011 (European Commission, 2005, 2011). While already in 2005 it stressed that "in reality integration takes place at the local level as part of daily life and everyone has a part to play", in 2011 a specific chapter of "More Action at Local Level" was added. Moreover it is noteworthy to mention that its renewed version, the document pointed at the needs of adapted integration approaches for highly skilled migrants, given the different integration challenges faced by various types of migrants.

\section{Local or Urban Dimension of Expat Policy}

The relevance of expats for the public administration becomes obvious if considered that, on one side, governments foster economic attractiveness of the territories and focus on catching human capital, and, on the other, governments are encouraged to develop integration policies to allow better participation of migrants in the economic and social life. Especially the local/ urban dimension of expat integration policy becomes meaningful given the growing emphasis on local/city level in both economic development and in integration. In order to shape appropriate public policies and "tailor" the integration approaches, public authorities need to know the

9 In Turkey, the 10th Development Plan (SPO, 2014) sets the following objectives: "617. Regional Development Agencies will place emphasis to attracting foreign capital investments in order to exploit regional potentials.", "931. Regional investment support and promotion strategies supporting the national strategies for foreign direct investment will be formulated. Efficiency and inter-institutional coordination in this field will be enhanced." 
expats and their needs. This requires specific studies and appropriate mechanisms of interaction to assure healthy feedback from expats. The expat oriented studies should look into not only the "traditional" aspects of the city like its economic performance, quality of private sector services, opportunities in terms of culture, entertainment and sports, but also from points of view of the organization of public sector services, such as transportation, environmental protection, garbage collection, green spaces, as well as residence and work permits, various authorizations for registering business or acquiring property, public health, accessibility of public institutions and public information for expats, management of their complaints etc.

This study aims to establish a link between expats and public policy field. And specifically to analyze the phenomenon of expats through the point of view of public policy and the public policy in the eyes of the expats in Istanbul. The research aims at finding answers to the following key questions:

1. Do national and local policy actors and instruments promote the attractiveness of Turkey and Istanbul and do they bear a specific focus on expats?

2. Do national and local policy actors and instruments promote integration policy?

3. How expats in Istanbul assess the policies /services of national and local public actors?

\section{Expats Eyed by Attractiveness Strategies}

Various policy making institutions put great emphasis on the promotion of Turkey as the "safe haven" for foreign direct investments for the stimulation of the economic growth, and Istanbul plays particular role in those plans. More important, these actors are increasingly aware of the importance of attracting qualified foreign professionals for achieving these goals. This is illustrated in various policy decisions and public discourse by the officials that highlight the growing relevance of the expat phenomenon for public authorities.

Thus, Turkish public actors increasingly adopt the discourse of "attractiveness", and use Istanbul as a major asset. The Turkish Investment Support and Promotion Agency (ISPAT), founded in 2006 with the objective of "promoting Turkey's investment opportunities to the global business community", praises the performance of the country whose "economy has shown remarkable performance with its steady growth over the last decade" (ISPAT a). Striving further to promote Turkey as the best place to invest and to live for expats, ISPAT stresses that "an increasing number of people from various parts of the world are moving to Turkey to start a new life, to work or even to find peace of mind for their retirements. [...] Most of Turkey's new residents hail from countries like the UK, Germany, Ireland, Denmark, the Netherlands, Norway, Austria, Belgium, France and the USA. Turkey is a privileged place to live for expatriates and their families" (ISPAT b). "Thanks to a recent amendment in Turkey's property law that lifted the reciprocity principle, foreign homebuyers and investors from all over the world are free to purchase property in one of 
the most promising real estate markets in the world" (ISPAT c).

On the other side, the 10th Development Plan (the national development strategy paper) puts emphasis on "attracting qualified [...] foreign people from overseas to the economy, making necessary arrangements for this purpose" (SPO, 2014: 171) and dedicates to this issue a whole chapter "1.20 Attracting Qualified Human Resources" which underlines that "the target group of the program is highly qualified international human power". This objective is to be achieved through, among other, component of "Improving Work and Living Environment". Such focus comes from the observation that "countries can make their development processes more competitive by utilizing global high quality human capital. Compared to developed countries, Turkey is not benefiting sufficiently from the highly qualified international human capital". Therefore the "number of qualified foreign professionals will be increased [...] by selective approach" (SPO, 2014: 49, 188).

In their endeavor for country's better position in the global spheres, the Turkish officials adopt various strategic orientations that are conducive to attract the human capital. Among them is the decision to set Istanbul as major financial center in the broad region. The government's policy document "Istanbul International Financial Center" also foresees the attraction of highly qualified labor. In this respect, the "Strategy and Action Plan for Istanbul International Financial Center (IFC-Istanbul)" adopted by the State Planning Organization sets the Priority 21 "Qualified work force shall be attracted to Istanbul" and stresses that "qualified foreign human resources shall be attracted to Turkey. Further, a talent pool [...] to recruit the work force needed for the financial center [...] shall be created as one of its priorities" (SPO, 2009: 21). Moreover, the official discourse considers that public policies shall aim at improving the living conditions and ease the settlement of the "desired" foreigners. Thus, in addition to the "work permit processes for foreigners shall be accelerated" according to Priority 21/73, the Priority 16 of IFC Plan states that "Living standards, security and transport means shall be upgraded in Istanbul", and subsequently calls "to improve and develop health, education, recreation, accommodation and hospitality facilities to serve foreigners" (SPO, 2009: 17). Echoing this approach, the Search Conference organized by the Istanbul Infrastructure Committee, one of the working groups of IFC $^{10}$, proposes actions such as "providing the means for foreign born population to learn the Turkish language [...]; assisting foreign born students in terms of orientation and integration to the system by national education policies; taking the necessary measures to ensure [that] children from abroad continue studying in Turkey [...]; improving the quality of pre-school institutions for foreign born children of age $0-5$ ". The same committee also claims that fostering integration and orientation of foreigners shall pass by adaptation of the education and the social security sectors to foreigners' needs (IFCIstanbul Project Office, 2011).

10 According to the website of Istanbul Infrastructure Committee, it is chaired by the Secretary General of Istanbul Metropolitan Municipality.http://ifm.ibb.gov.tr/en-US/Pages/Home.aspx 
Finally, there are also other policy instruments that have indirect but significant impact on the attractiveness of Istanbul. As Daoudov and Bozlagan have long argued, the city on the Bosporus is the "most easily accessible global city from land, sea and air" if considered its uniquely combined advantage of a large number of direct flight connections ${ }^{11}$ and the largest number of world's passports that do not need prior visa arrangement to access it, due to Turkey's liberal visa regime (Bozlagan, Daoudov, 2008; Daoudov, 2009a, 2009b). ${ }^{12}$

The public actors at local level also align their efforts with the national discourse of attractiveness of Istanbul for expats. Thus, Istanbul Development Agency (ISTKA) ${ }^{13}$ states that "Istanbul has cemented itself as the darling of investors looking for strong returns without any risk" (ISTKA 2014a) and informs that "recent changes have eased restrictions on foreign ownership of Turkish real estate, as the government seeks to court international capital and transform Istanbul into a regional financial center". ISTKA also adds that "foreign investors continue to flock to Istanbul" and that "educational institutions have leveraged Istanbul's diversity to build strong multicultural and international linkages and programs [...] [that] benefit local businesses by strengthening their access to $[\ldots]$ international talents". It stresses the willingness to make Istanbul "center of attraction" for foreign scientists and "qualified global manpower" (ISTKA, 2014b: 3, 7).

The benefits of "increasing the cultural diversity" are also put forward for Istanbul which "is a multicultural place with numerous foreign citizens" (ISTKA, 2012, 2013, 2014a) and "world's privileged meeting point". Istanbul's virtues for expats are extolled in diverse and eloquent ways in various official publications. ${ }^{14}$

\section{Focus on Local Integration of Expats}

With its emerging economy, evolving democracy and increasing political power, Turkey is steadily turning from a country of emigration into an attractive destination for immigration (Daoudov 2013; DGMM; Pérouse, 2013). As a result, Turkey witnesses major changes in its

11 Indeed, the Turkish flag carrier Turkish Airlines flies to the highest number of countries in the world.

12 In fact, the citizens of several countries require a visa sticker, obtained for a small fee, upon arrival at the Turkish border. (Daoudov, 2009a). Also, holders of visa or residence permit from any of the Schengen or OECD countries are eligible for Turkish e-Visas procedure (E-Visa).

13 The Istanbul Development Agency (ISTKA, istka.org.tr) is a hybrid organization governed by representatives of the national and local governments as well as private sector. Although chaired by the Governor of Istanbul, the agent of the central government, its mandate is to foster development in Istanbul. For this functional reason ISTKA is taken here in the category of local actors.

14 Consider this almost poetic citation from ISTKA's Istanbul Fact Sheet 2014: "A setting of majestic beauty, an enviable climate, and an unsurpassed quality of life... Istanbul is one of the most dynamic and diverse economies in Europe. No wonder Istanbul is a magnet for intelligent, talented people from around the world [...] ready to present opportunities for international investors.[...] And the global economy is at Istanbul's doorstep[...] Keeping that in mind, Istanbul is a world class city of opportunities. [...] As the city continues to attract large numbers of international migrants due to its bright performance after the global economic crisis, the talent pool grows in skill and diversity. In Istanbul investors are fortunate to draw talent from a creative, cosmopolitan, highly-educated labor pool. Its excellent universities and superb quality of life have made the city a magnet for professionals [...]". 
migration management policy. On the political and government level, there is a rising awareness that immigration is an inevitable consequence of country's economic development, moreover, that it can be an element which enriches the economy. The public discourse puts emphasis on the beneficial sides of migration and places it in the context of "worldwide increase in demand for skilled labor and free movement of labor" that "offer several opportunities for Turkey". Therefore, it is believed that "promoting intellect migration to Turkey [... ] will positively contribute to growth potential. [...] On the other hand, becoming an attraction center in education and health will provide Turkey the opportunity to benefit maximally from international mobility" (SPO, 2014: 10). This transformation is translated into novel legal and administrative tools, such as the adoption of the new Law on Foreigners (Law 6458) and other related legislations (on work permit, foreign direct investment etc.), the establishment in 2014 of civil authorities and platforms to coordinate and implement the migration policies, such as the Directorate General of Migration Management in the Ministry of Interior, and the Migration Policies Board, or intention to establish Advisory Council for Foreign Labor. ${ }^{15}$ All these policies and actors seek to contribute harmoniously "to develop an effective migration management system which supports the economy" (SPO, 2014: 50).

However the success of the migration policy depends not only on the capacity to attract "talents" but also to satisfy them, by creating favorable physical, social or cultural living conditions. The resources cited above point at the considerable level of awareness of the social and cultural dimensions of labor migration among the policy makers. Moreover for the first time the concept of integration of migrants, which was up until recently unknown to policy makers in Turkey (Ertuna Lagrand, 2010: 259), has been introduced with the Law of Foreigners in 2014 (Daoudov, 2013: 7; Açıkgöz, Arıner, 2014: 22). Interestingly, the English word "harmonization", rather than the more common "integration" was consciously chosen to represent the Turkish concept of "uyum". According to this approach, the concept of integration (as commonly used in Europe/the West) foresees unilateral adaptation to the host society, while the Turkish concept of harmonization points at mutual adaptation of foreigners and locals in order to achieve harmony, expressed as the need to "facilitate the mutual harmonization" (Daoudov, 2014: 6; DGMM).

While central government actors have introduced harmonization as policy objective, the awareness and involvement by the local governments (municipalities) in this field is less evident in Turkey. Although, at the local level there is also clear emphasis on or tendency of branding the cities, attracting investments, investors and talents, these aspirations are not translated into concrete policies that would focus on the human dimension of such policy. In fact, to the contrast with their European or Western counterparts, the local governments in Turkey don't have tradition of actively dealing with foreigners, nor are they really involved in the policies and strategies designed by the national authorities related with the matter. This state of things can be explained by several factors. First of all, the focus on integration or harmonization is itself a new phenomenon for Turkey. Second, the issues related to international migration have been

15 Announced by Prime Minister Davutoğlu during his conference (Davutoglu, 2015). 
traditionally dealt exclusively by the central government, and with a security-centered approach (Açıkgöz, Arıner, 2014). There have been few initiatives or exceptions to this reality in Turkey, where local government had an interest in dealing with foreigners and had developed specific local policies or tools. ${ }^{16}$

Nevertheless, with the new Law on Foreigners, a link, although fairly weak one, has been established between the harmonization policy and the local governments. Thus the local authorities are expected to provide "recommendations and contributions" to the General Directorate of Migration Management in the planning of harmonization activities, which is rather a limited role to play (Daoudov, 2014). However, it can be expected that the above mentioned developments will increase the awareness and involvement of local governments, in particular in Istanbul, of the importance of dealing with the integration of foreigners and specifically of expats.

\section{Public Policies as seen by Expats}

To summarize what preceded, the public administration is willing 1) to make Turkey and Istanbul an attractive center for investment and economic development, 2) to attract qualified labor force or talents, 3) to create favorable living conditions for the expats, 4) to develop integration/ harmonization policy. In this light, it is important to understand how the expats assess the results of these policies. In other world, how they evaluate the city's attractiveness (in terms of its infrastructure and services) and the "care" of the public actors about the expats. This analysis will help to evaluate to which extent the policy orientations are translated into actions and have a positive impact on the expats.

The questionnaire of the "Study on the Socio-Economic and Cultural Situation of Highly Qualified Foreign Professionals (Expats) Working/Living in Istanbul and their Assessment of the Public and Private Sector Service-Provision in the City" was designed with the objective of getting insight into the expats' perception. As stated in the introductory letter of the survey, "all local players, starting with the public authorities, must assume their responsibilities in order to make the city attractive to those talents, to make it livable and full of opportunities. In particular, it is of great importance that the local authorities know and understand the phenomenon of international labor force, that they take it into account when shaping their general policies; moreover, that they develop specific policies towards expats. The present work, which brings together university and municipal union, has the objective to study the phenomenon, to analyze the findings, and later, to elaborate and to submit concrete recommendations to the local decision-makers." (IStPat 34) Here below are presented some key findings of the survey, selected in terms of relevance for subject of the article.

16 Among few examples can be cited the activities and initiatives by the Union of Municipalities of Marmara, with the involvement of the authors, the activities of the Zeytinburnu [district] Municipality in Istanbul, as well as "Foreigners Committees" under the town councils (municipal advisory bodies) of the municipalities of Alanya, Konyaatl, Bursa. 


\section{The General Profile of the Respondents}

The majority of respondents that participated in the survey (58\%) are between 26-45 years old. 47\% of them hold graduate degree (MA or PhD), while 44\% have Bachelor degree. 66,67\% are women. Only $13,75 \%$ came to Istanbul in the framework of intra-company transfer, while $65 \%$ came for new job/employer and $21,25 \%$ do not have job. $61,61 \%$ have poor or faire command of Turkish, while $35,35 \%$ have excellent or good level of the local language. $65,31 \%$ of them study Turkish, and $87,50 \%$ of them consider that studying Turkish language is necessary for the life and work to be easier. For $87,50 \%$ of the respondents, English is the main language in private life, followed by 15,63 \% for French, 8,33\% for German, 5,21\% for Spanish, 3,13\% for Arabic, 2,08\% for Russian and $1,04 \%$ for Chinese. As to the language they use for the work, English leads with $92,05 \%$, followed by Turkish with 42,05\%, French with 9,09\%, Spanish with 5,68\%, Russian with 3,41\%, German with $3,41 \%$, and Arabic with 2,27\%. In terms of interaction among themselves (multiple choice answer was possible), 39,18\% of expats attend regular meetings organized by expat associations/clubs, $51,55 \%$ interact with other expats through internet (sites, blogs, social media...), 46,39\% gather randomly in occasional public places like cafes/restaurants, very little $(5,15 \%)$ with the help or at the premises of consulate/embassy, while $22,68 \%$ don't contact with other expats at all. Among them, $80,41 \%$ have regular contacts with expats from other countries then their own, while 19,59\% don't.

Table 1: Nationality of the respondents.

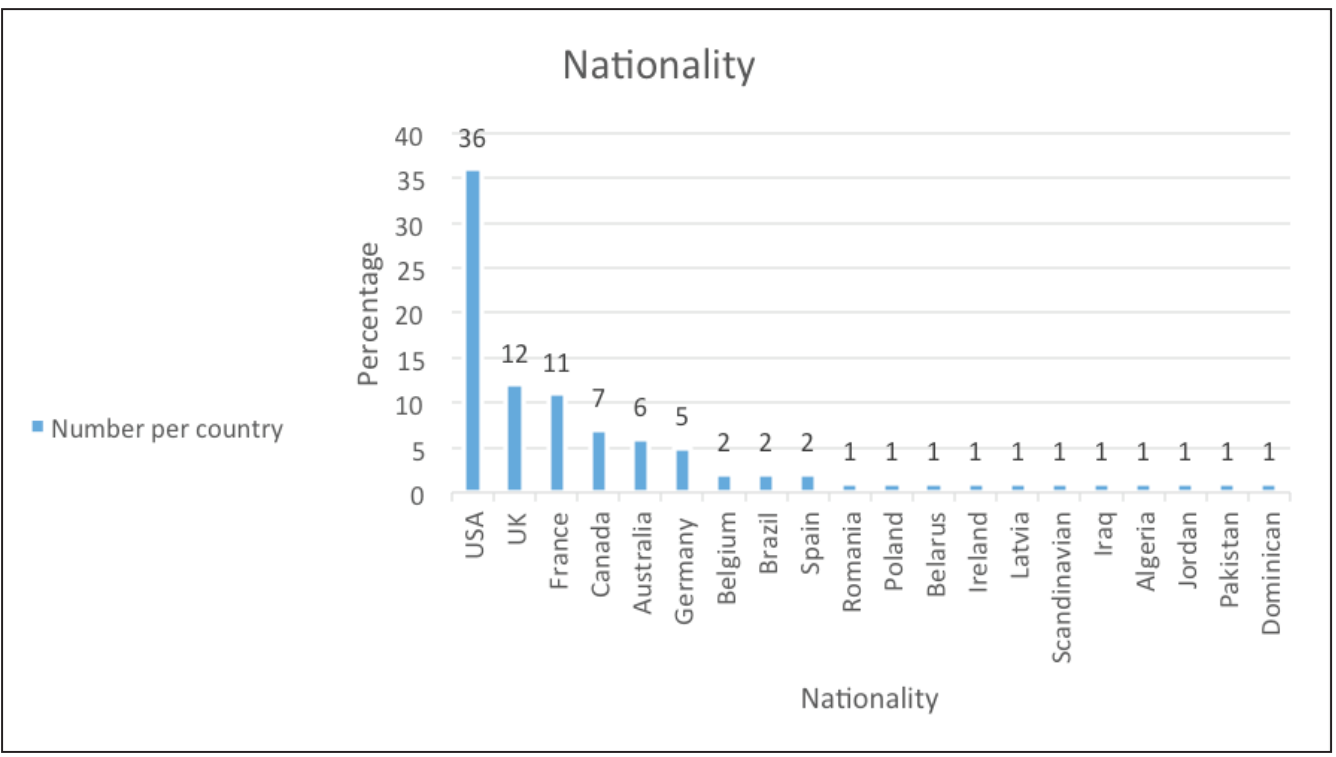

The respondents have very good impression of Istanbul (93,33\% find it nice or very nice city) and good relations with Turks (98,95\% good or very good), although Turkish culture is mostly very different from theirs (78,12\% find it different or very different). 63,92\% of them mostly don't 
or never face integration problems, and 53,09\% of them even think to settle forever in Istanbul. $80,90 \%$ have no contacts with Turkish civil society organizations, and 15,73\% have only random contacts. As to the effectiveness of expat associations in protecting the rights and interests and in improving the life of expats, 20,97\% find that these are active, 35,48\% find them active but not sufficiently, and $43,55 \%$ believe they are not active. $76 \%$ of them consider that media resources (press, website, TV) in Istanbul are available in English. And in order to get informed about the general life and the political \& social agenda in Turkey, 40,82\% follow Turkish press and media, $69,39 \%$ follow international press and media about Turkey, 58,16\% get information from local newspapers/websites available in English or in their language, and 16,33\% from the information sources distributed by consulates/embassies.

\section{Expats' Assessment of Services in the City}

The respondents have assessed the services provided by the private sector and, as it appears in the Table 2, they are mainly satisfied with their level. Among these especially healthcare, banking and insurance, hotels, translation and tourist guiding, and travel agencies are best rated. However the business associations and chambers of commerce and industry seem to be less well known to the expats to they are mostly neutral about them. Finally, on notary and lawyer services the opinions seem to be divided.

Table 2: Answers to the Question: What do you think about the overall quality of services listed below, provided by the private sector in Istanbul?

\begin{tabular}{|c|c|c|c|c|c|c|}
\hline & $\begin{array}{l}\text { Very } \\
\text { good }\end{array}$ & Good & Neutral & Bad & $\begin{array}{l}\text { Very } \\
\text { bad }\end{array}$ & $\begin{array}{l}\text { Overall } \\
\text { Response }\end{array}$ \\
\hline Health care & $\begin{array}{r}\% \mathbf{3 0 , 6 1} \\
30\end{array}$ & $\begin{array}{r}\% 39,80 \\
39\end{array}$ & $\begin{array}{r}\% 22,45 \\
22\end{array}$ & $\begin{array}{r}\% 7,14 \\
7\end{array}$ & $\begin{array}{r}\% \mathbf{0 , 0 0} \\
0\end{array}$ & 96 \\
\hline Banking and insurance & $\begin{array}{r}\% \mathbf{1 8 , 3 7} \\
18\end{array}$ & $\begin{array}{r}\% 37,76 \\
37\end{array}$ & $\begin{array}{r}\% 25,51 \\
25\end{array}$ & $\begin{array}{r}\% \mathbf{1 6 , 3 3} \\
16\end{array}$ & $\begin{array}{r}\% 5,10 \\
5\end{array}$ & 96 \\
\hline Hoiel services & $\begin{array}{r}\% \mathbf{3 7}, \mathbf{2 3} \\
35\end{array}$ & $\begin{array}{r}\% 43,62 \\
41\end{array}$ & $\begin{array}{r}\% 20,21 \\
19\end{array}$ & $\begin{array}{r}\% 0,00 \\
0\end{array}$ & $\begin{array}{r}\% 0,00 \\
0\end{array}$ & 94 \\
\hline Travel agencies & $\begin{array}{r}\% 13,64 \\
12\end{array}$ & $\begin{array}{r}\% 35,23 \\
31\end{array}$ & $\begin{array}{r}\% 46,59 \\
41\end{array}$ & $\begin{array}{r}\% 5,68 \\
5\end{array}$ & $\begin{array}{r}\% 1,14 \\
1\end{array}$ & 86 \\
\hline Real estaie services & $\begin{array}{r}\% 3,23 \\
3\end{array}$ & $\begin{array}{r}\% 19,35 \\
18\end{array}$ & $\begin{array}{r}\% 44,09 \\
41\end{array}$ & $\begin{array}{r}\% \mathbf{2 6 , 8 8} \\
25\end{array}$ & $\begin{array}{r}\% 8,60 \\
8\end{array}$ & 93 \\
\hline Noiary and lawyer services & $\begin{array}{r}\% \mathbf{1 , 1 0} \\
1\end{array}$ & $\begin{array}{r}\% 25,27 \\
23\end{array}$ & $\begin{array}{r}\% 51,65 \\
47\end{array}$ & $\begin{array}{r}\% 19,78 \\
18\end{array}$ & $\begin{array}{r}\% 3,30 \\
3\end{array}$ & 91 \\
\hline Transbation and tourist guiding & $\begin{array}{r}\% 5,81 \\
5\end{array}$ & $\begin{array}{r}\% 38,37 \\
33\end{array}$ & $\begin{array}{r}\% 43,02 \\
37\end{array}$ & $\begin{array}{r}\% 11,63 \\
10\end{array}$ & $\begin{array}{r}\% \mathbf{1 , 1 6} \\
1\end{array}$ & 86 \\
\hline Press and media services & $\begin{array}{r}\% 3,33 \\
3\end{array}$ & $\begin{array}{r}\% 32,22 \\
29\end{array}$ & $\begin{array}{r}\% 43,33 \\
39\end{array}$ & $\begin{array}{r}\% 11,11 \\
10\end{array}$ & $\begin{array}{r}\% 11,11 \\
10\end{array}$ & 90 \\
\hline $\begin{array}{l}\text { Services of commerce and industry } \\
\text { chambers }\end{array}$ & $\begin{array}{r}\% 3,90 \\
3\end{array}$ & $\begin{array}{r}\% 22,08 \\
17\end{array}$ & $\begin{array}{r}\% 64,94 \\
50\end{array}$ & $\begin{array}{r}\% 5,19 \\
4\end{array}$ & $\begin{array}{r}\% 3,90 \\
3\end{array}$ & 77 \\
\hline Business associations & $\begin{array}{r}\% \mathbf{2 , 6 0} \\
2\end{array}$ & $\begin{array}{r}\% 18,18 \\
14\end{array}$ & $\begin{array}{r}\% 75,32 \\
58\end{array}$ & $\begin{array}{r}\% 3,90 \\
3\end{array}$ & $\begin{array}{r}\% \mathbf{1 , 3 0} \\
1\end{array}$ & 77 \\
\hline
\end{tabular}


The assessment of the services provided by the central government agencies varies depending on the institution. Thus, the institutions related with the procedures of the work permit and the residence permit receive rather a negative evaluation by expats (see Table 3 ).

Table 3: Answers to the Question: What do you think about the services provided by central government authorities?

\begin{tabular}{|c|c|c|c|c|c|c|}
\hline & $\begin{array}{l}\text { Very } \\
\text { good }\end{array}$ & Good & Neutral & Bad & $\begin{array}{l}\text { Very } \\
\text { bad }\end{array}$ & $\begin{array}{l}\text { Overall } \\
\text { Response }\end{array}$ \\
\hline $\begin{array}{l}\text { Labour and Social Security Ministry } \\
\text { (work permit etc) }\end{array}$ & $\begin{array}{r}\% 1,27 \\
1\end{array}$ & $\begin{array}{r}\% \mathbf{2 0 , 2 5} \\
16\end{array}$ & $\begin{array}{r}\% 32,91 \\
26\end{array}$ & $\begin{array}{r}\% 29,11 \\
23\end{array}$ & $\begin{array}{r}\% 17,72 \\
14\end{array}$ & 79 \\
\hline Tax offices & $\begin{array}{r}\% 2,70 \\
2\end{array}$ & $\begin{array}{r}\% 13,51 \\
10\end{array}$ & $\begin{array}{r}\% 55,41 \\
41\end{array}$ & $\begin{array}{r}\% \mathbf{2 0 , 2 7} \\
15\end{array}$ & $\begin{array}{r}\% 8,11 \\
6\end{array}$ & 74 \\
\hline Land registry and cadastre offices & $\begin{array}{r}\% 3,57 \\
2\end{array}$ & $\begin{array}{r}\% 12,50 \\
7\end{array}$ & $\begin{array}{r}\% 58,93 \\
33\end{array}$ & $\begin{array}{r}\% 19,64 \\
11\end{array}$ & $\begin{array}{r}\% 5,36 \\
3\end{array}$ & 56 \\
\hline $\begin{array}{l}\text { Foreigners Office of Police (residence } \\
\text { permit etc) }\end{array}$ & $\begin{array}{r}\% 6,98 \\
6\end{array}$ & $\begin{array}{r}\% 29,07 \\
25\end{array}$ & $\begin{array}{r}\% \mathbf{1 7}, \mathbf{4 4} \\
15\end{array}$ & $\begin{array}{r}\% 30,23 \\
26\end{array}$ & $\begin{array}{r}\% 16,28 \\
14\end{array}$ & 86 \\
\hline $\begin{array}{l}\text { Security forces (police \& } \\
\text { gendarmerie) }\end{array}$ & $\begin{array}{r}\% 6,67 \\
5\end{array}$ & $\begin{array}{r}\% \mathbf{2 0 , 0 0} \\
15\end{array}$ & $\begin{array}{r}\% 38,67 \\
29\end{array}$ & $\begin{array}{r}\% \mathbf{2 0 , 0 0} \\
15\end{array}$ & $\begin{array}{r}\% \mathbf{1 4}, 6 \mathbf{7} \\
11\end{array}$ & 75 \\
\hline Ministry of National Education & $\begin{array}{r}\% \mathbf{1}, \mathbf{4 7} \\
1\end{array}$ & $\begin{array}{r}\% 4,41 \\
3\end{array}$ & $\begin{array}{r}\% 52,94 \\
36\end{array}$ & $\begin{array}{r}\% \mathbf{2 6 , 4 7} \\
18\end{array}$ & $\begin{array}{r}\% 14,71 \\
10\end{array}$ & 68 \\
\hline $\begin{array}{l}\text { Governorship/ District sub- } \\
\text { governorships (valilik/kaymakamlik) }\end{array}$ & $\begin{array}{r}\% \mathbf{1 , 6 7} \\
1\end{array}$ & $\begin{array}{r}\% 13,33 \\
8\end{array}$ & $\begin{array}{r}\% 61,67 \\
37\end{array}$ & $\begin{array}{r}\% \mathbf{2 0 , 0 0} \\
12\end{array}$ & $\begin{array}{r}\% 3,33 \\
2\end{array}$ & 60 \\
\hline
\end{tabular}

On the question if they have easy access as expats to services provided by the central government authorities, for 5,4\% of the respondents "everything is foreseen to make it easy for expats", 46,7\% find that "sometimes it is easy sometimes difficult", and $47,8 \%$ that "it is always difficult for an expat". As to whether the central authorities do provide information in English or other foreign languages (on websites, in their regular publications etc.), only 6,4\% think that they provide it and that the information is sufficient, $64,9 \%$ say such information is provided but is not sufficient, for $17 \%$ the information is available only in Turkish, while 11, $7 \%$ don't know whether or not it is done. As to the question whether national authorities or political parties have expat-oriented activities or policies, $60,2 \%$ do not know about it and 39,8\% believe they don't have. Actually none considers that they do have such policy.

After the central authorities, the municipalities' services have also been assessed by expats, as appears in the Table 4. 
Table 4: Answers to the Question: How do you assess the services of the local authorities (municipalities and their related bodies)?

\begin{tabular}{|c|c|c|c|c|c|c|}
\hline & $\begin{array}{l}\text { Very } \\
\text { good }\end{array}$ & Good & Meutral & Bad & $\begin{array}{l}\text { Very } \\
\text { bad }\end{array}$ & $\begin{array}{l}\text { Overall } \\
\text { Response }\end{array}$ \\
\hline Cleaning of public spaces & $\begin{array}{r}\% 20,00 \\
18\end{array}$ & $\begin{array}{r}\% \mathbf{5 1 , 1 1} \\
46\end{array}$ & $\begin{array}{r}\% 11,11 \\
10\end{array}$ & $\begin{array}{r}\% 12,22 \\
11\end{array}$ & $\begin{array}{r}\% 5,56 \\
5\end{array}$ & 90 \\
\hline Garbage collection & $\begin{array}{r}\% 23,60 \\
21\end{array}$ & $\begin{array}{r}\% \mathbf{4 9 , 4 4} \\
44\end{array}$ & $\begin{array}{r}\% 16,85 \\
15\end{array}$ & $\begin{array}{r}\% 7,87 \\
7\end{array}$ & $\begin{array}{r}\% 3,37 \\
3\end{array}$ & 89 \\
\hline Environmental protection & $\begin{array}{r}\% 3,45 \\
3\end{array}$ & $\begin{array}{r}\% 8,05 \\
7\end{array}$ & $\begin{array}{r}\% 18,39 \\
16\end{array}$ & $\begin{array}{r}\% \mathbf{4 0 , 2 3} \\
35\end{array}$ & $\begin{array}{r}\% 29,89 \\
26\end{array}$ & 87 \\
\hline Parks and green spaces & $\begin{array}{r}\% 9,89 \\
9\end{array}$ & $\begin{array}{r}\% 32,97 \\
30\end{array}$ & $\begin{array}{r}\% 24,18 \\
22\end{array}$ & $\begin{array}{r}\% \mathbf{1 6 , 4 3} \\
15\end{array}$ & $\begin{array}{r}\% \mathbf{1 7}, \mathbf{5 8} \\
16\end{array}$ & 91 \\
\hline Urban transport & $\begin{array}{r}\% 15,73 \\
14\end{array}$ & $\begin{array}{r}\% 35,96 \\
32\end{array}$ & $\begin{array}{r}\% 30,34 \\
27\end{array}$ & $\begin{array}{r}\% 13,48 \\
12\end{array}$ & $\begin{array}{r}\% 5,62 \\
5\end{array}$ & 89 \\
\hline Social \& cultural activities & $\begin{array}{r}\% 8,22 \\
6\end{array}$ & $\begin{array}{r}\% 24,66 \\
18\end{array}$ & $\begin{array}{r}\% 57,53 \\
42\end{array}$ & $\begin{array}{r}\% 9,59 \\
7\end{array}$ & $\begin{array}{r}\% 0,00 \\
0\end{array}$ & 73 \\
\hline $\begin{array}{l}\text { Vocational training (provided by } \\
\text { ISMEK and similar) }\end{array}$ & $\begin{array}{r}\% 4,17 \\
2\end{array}$ & $\begin{array}{r}\% 12,50 \\
6\end{array}$ & $\begin{array}{r}\% 68,75 \\
33\end{array}$ & $\begin{array}{r}\% 10,42 \\
5\end{array}$ & $\begin{array}{r}\% 4,17 \\
2\end{array}$ & 48 \\
\hline
\end{tabular}

Interestingly, while the majority finds that cleaning of public spaces $(71,11 \%)$ and garbage collection $(73,04 \%)$ are well organized in Istanbul, 70,12\% of them give negative marks to the environmental protection. This seems to reflect expats' conception of the protection of the environment as a broader set of measures than mere garbage collection and street cleaning. $51,69 \%$ are satisfied with urban transportation. Remarkably, the majority of expats is unaware of social and cultural activities and vocational trainings offered by the municipalities.

In contrast with the access to the services of the central government, only $1,2 \%$ consider that "everything is foreseen to make it easy for expats" (5,4\% in the case of central authorities), 41,7\% find that "sometimes it is easy sometimes difficult", and 57, 1\% that "it is always difficult for an expat". As to whether the municipalities provide information in English or other foreign languages (on websites, in their regular publications etc.), only $1,1 \%$ think that they provide it and that the information is sufficient (against 6,4\% for the central government), 35,6\% say such information is provided but not sufficient $(64,9 \%$ for the central government), for $36,7 \%$ the information is available only in Turkish (17\% for the central government), while $26,7 \%$ don't know whether or not it is done (11,7 \% for the central government). It clearly appears, in comparison with the central government agencies, that the municipalities lack institutional communication directed to and accessible to expats. This observation is corroborated by the fact that $52,7 \%$ do not know if municipalities have specialized staff or units to serve foreigners/expats, 35,5\% of the participants are convinced that they actually don't have them, 9,7\% state that such units exists but are insufficient, and only 2,2\% respond that they exist and do well their job. 
When asked whether municipalities have specific policies or services for better integration of expats, only 1,1\% answer "yes", while 41,9\% are convinced that there are no such policies, and $57 \%$ don't know whether or not such work is done by municipalities. As to their opinion about citizen participation by expats in the local public life (multiple choice possible), according to 51,3\% municipalities should have consultative structures to involve expats, for 5,1\% such structures and policy exist and are sufficient, $14,1 \%$ are not interested by local public life, and $32,1 \%$ actually believe that local public life is not for expats as they are only "guests" in the city. 93,3\% are not aware of the existence of consultative town council (kent konseyi) in their municipality, 5, 6\% say that the town council doesn't deal with expats, and only 1, 1\% think it is helpful to them. The question "Which municipalities are most successful in providing services to expats?" reveals that $12,5 \%$ think that Istanbul Metropolitan Municipality is successful in contrast with 2,5\% that think that the district municipality they live or work in, and 2,5\% that believe that other district municipality than the one they live or work is so. However $22,5 \%$ say that actually none of them is successful in serving expats, and 57,5\% don't know the difference between those (levels of) municipalities.

In closing, $23,1 \%$ of respondents think that, when compared to other cities they lived before, the life in Istanbul is very good, $15,4 \%$ think it is better, $32,1 \%$ find it similar, $28,2 \%$ consider it is worse, and 1,3\% even assess it as very bad.

\section{Discussion About the Findings}

As mentioned earlier, the current analysis focuses on few key findings that are in direct relation with the main subject. First of all, the respondents of the questionnaire correspond well to the dominant "expat" image in that they come from the industrialized countries or the Global North, as $86 \%$ of the respondents are from OECD and EU member countries. $91 \%$ have higher education (undergraduate or graduate degrees), more than two thirds of them are women. Only one seventh of them come through intra-company transfer (the narrow "ICT expats"), two-thirds come for a new job, and one fifth don't have a job yet in Istanbul. So it can be considered that the expats come from the developed countries, they have qualifications, they are attracted by the opportunities offered or promised by Istanbul or probably came to create them.

The expats seem in general to be charmed by Istanbul and are very positive about Turkey and the Turkish society ${ }^{17}$. This general positive approach gradually decreases when confronted with the task of assessing the services (offered respectively by private sector, by central and then local governments). When they are invited to make a closer examination of their encounter with the city and its administration, the initial "excitement" leaves its place to more pragmatic evaluation. Thus, while in the beginning of the questionnaire the $93 \%$ of expats found Istanbul (very) nice and

17 Remarkably, HSBC Expat Explorer Survey, which placed Turkey as 26th best country for expats in its worldwide ranking, chose the following words as its flagship expat citation to describe Turkey: "Prepare to be delighted. Turkish people are the most friendly people I've ever met". 
$53 \%$ even envisaged settling here definitively, there is a visible drop in this enthusiasm at the end of the survey. While only $38,5 \%$ find the life in Istanbul better or much better compared to their former experiences, for the majority of respondents the life either offers nothing new $(32,1 \%$ find it similar) or proved to be even worse $(29,3 \%)$. This contrast can be explained by two factors. First of all, along the questionnaire the respondents have been invited to explicit their own experience with the city in terms of services and policies. Here inevitably many of the shortcomings or even problems faced may come to the surface, which mitigates their enthusiasm about Istanbul. This observation can also be corroborated by the consideration that in the beginning they are asked about Istanbul as a city (question that puts Istanbul in the center), while later they respond about their daily life (question that focuses on them in the city).

This finding also calls the following consideration. Undoubtedly Istanbul's attractiveness as city, place and brand is a clear asset for any policy that would seek to gain the human capital. But if this attractiveness will not be supported by effective public policies and qualitative services tailored to expats, this advantage risks to fade away along the confrontation with the realities.

Another finding is that, despite the clear emphasis in various policy documents on attracting qualified migrations, little is done on the ground in terms of concrete policies and practices to help expats and to seek their satisfaction. National authorities, political parties or local governments seem to have no such clear policy or instruments that would be known to expats. No specialized units in the public institutions, no expat-oriented actions implemented by public actors, no expat involvement in the consultative structures seem to exist or to be a common practice in Istanbul. The town councils, the consultative structures established to strengthen participatory local democracy at municipal level, apparently don't involve or focus on expat communities. ${ }^{18}$ Neither seem the neighborhood headmen (muhtar) to be active in dealing with the expats, so to play the role of an effective intermediary between the community and the authority.

In other words, the public sphere in Istanbul is expat-blind. The grand discourses and inspiring policy orientations are not translated into meaningful and concrete policies at local level that would be visible to the expat community. Another indicator is that almost all respondents mentioned that this questionnaire is the first survey that they have encountered in Istanbul and that was launched by public actors to collect expats' feedback about the city. Obviously, little is done from the side of the public authorities to address specifically expats. There is a clichéd representation that skilled migrants or expats are disembedded and disengaged with local life (Nagel, 2005: 208), especially disconnected from local public life shall be revisited. Even though it appeared through the survey many of the expats in Istanbul themselves say they are not interested in or consider local public life is not for them, more than half of them wish to see consultative structures that would involve them. And other studies have shown that far from being above it all' or removed from local life, the skilled migrants are implicated in the politics through which the host society is continuously redefined (Nagel, 2005: 208).

18 The analysis of the available websites of the district town councils in Istanbul shows that non of them has specific committee or working group that focuses on foreigners/expats/immigrants. 


\section{Conclusions and Recommendations}

Since recent years, the national economic development strategy has put clear emphasis on attracting qualified labor force and human capital as one of the key tools of making Turkey in general and Istanbul in particular a pole of attraction. This discourse recognizes the need for importing human capital (along the national strategies of developing domestic human capital) as a key instrument to build a competitive economy. As a result, number of national and local level policy instruments call for attracting highly qualified labor migration, and recognize the necessity of creating favorable life and work conditions for the professionals and their families. On the other side, major transformation have occurred in the field of migration management, either through modernization of what exists or establishment of new institutions. Within this evolution, the concept of harmonization of immigrants with the host community has been introduced.

These developments require visible repercussions on the ground. In particular, the guiding policy orientations should be translated into concrete tools and practices by public administration in Istanbul, the city which is given a key mission as the center of attraction. Moreover, since a decade Turkey witnesses the decentralization reform process that considerably strengthened local governments, especially metropolitan municipalities in the large cities. All this would naturally call for a greater and direct involvement of Istanbul Metropolitan Municipality and district municipalities in the efforts to make the city attractive and hospitable to expats.

However the close examination of the situation at the institutional level and through the feedback by the expats revealed that little is done, yet, on the ground to translate the vision into reality. At the national level, this insufficiency be explained by the fact that the whole migration management system is itself still in the making process. As to the local government level, neither has the legal and administrative empowerment in this particular field been promoted nor has the awareness of their potential role taken place. Especially the lack of awareness ${ }^{19}$ prevents them from taking proactive role and actively using or adapting the existing tools, such as the town councils. ${ }^{20}$

Metropolitan and district municipalities as major public actors in Istanbul, and especially in those areas of the city where expats traditionally settle or those that witness rapid economic development likely to attract expat communities, should take conscious actions to adapt their structures and policies.

To list a non-exhaustive list of recommendations ${ }^{21}$, the authors propose to adopt series of

19 Turkish local governments not only lack information about the key role and the rich experience accumulated in this field by local and regional governments in the European Union, but even about various instruments developed by the Council of Europe, of which Turkey is a full member.

20 The active use of such tools like town council is illustrated by the pioneering example (established in 2004) of the town council of Alanya Municipality (Province of Antalya). It has established under its structure the "Foreigners Committee" that specifically involves expat representatives. Since then this innovative experience has inspired other municipalities like Konyaaltı (Antalya) or Bursa to adopt similar approach.

21 For other recommendations see Daoudov (2014). 
measures along three main axes: 1) Development of knowledge and awareness, 2) Adaptation of services and policies, 3) Promotion and strengthening of the participation.

\section{1) Development of knowledge and awareness}

First of all, there is a need to study the international experience in expat-oriented policies, to learn from best practices (and failures) in other countries. Also the expat communities and their needs in Istanbul shall become subject of focused studies conducted or ordered by public actors. The information gathered from these sources shall be translated into actions for raising the awareness of public authorities (both national level and local level officials) about the need of expat-friendly public policy.

\section{2) Adaptation of services and policies}

The services and policies in Istanbul shall be revised and adapted to better fit the needs of expats. This can be achieved through two approaches: the creation of specific expat-oriented policies and tools, and the adaptation of general policies and tools to better respond to their needs. In terms of policies, it concerns various services offered and activities implemented by the public actors. As to the tools, these are the administrative units (departments, municipalities, muhtars) through which the administration interacts with citizen and serves them. Creation of specific "expat desks" in the municipalities of other official institutions with the staff that speaks foreign languages and is trained for intercultural work can be cited as example.

\section{3) Promotion and strengthening of the participation}

Last but not least, efforts should be directed at fostering the participation of expats in the public decision making in the light of the principles of participatory local democracy. This requires establishment of various participation, consultation and feedback mechanisms. Here again both adaptation of existing general tools and creation of expat-oriented specific tools can be used in complementarity. The town councils can form active expat sub-committees and can involve expat associations. Municipalities can establish advisory committees as flexible structures, in form of informal or semi-formal platforms. They can also design ad hoc consultation mechanisms with expat communities. They can designate an official interlocutor within their hierarchical structure, such as assigning the task to a deputy-mayor or a director. Similar coordination tools can be adopted at the level of central government units stationed in Istanbul, at the Governorate or at the level of provincial directorates (of education, of immigration etc.).

In closing, the effort of the survey launched in the framework of cooperation between the Union of Municipalities of Marmara and Istanbul Studies Department of Marmara University appears as a pioneering effort in Istanbul that aimed at measuring the expats' perception of the services in the city, of public actors' hospitality to them and their general awareness about the public sphere. The present article only covered a small part of that study, and it obvious that there is a lot to be done in order to bridge the gap between the desire of the authorities to profile Istanbul as the "second home" for expats and the concrete public actions that would let them feel welcome, feel at home. 


\section{References}

A.T. Kearney Global Cities Outlook (2012) The 2012 Global Cities Index and Emerging Cities Outlook, http://www.atkearney.com/documents/10192/dfedfc4c-8a62-4162-90e5-2a3f14f0da3a.

Açıkgöz, M. and H. O. Arıner (2014) “Turkey’s New Law on Foreigners and International Protection: An Introduction”, Turkish Migration Studies Group (TurkMiS) Briefing Paper 2, University of Oxford, https://www.compas.ox.ac.uk/fileadmin/files/Publications/Briefings/TurkMiS/Brief_2_A riner_ Acikgoz_2014.pdf

Calay, V. (2007) “D’une 'politique nationale de prestige' à un 'marketing urbain': les formes d’attractivité dans les politiques de valorisation des trois 'Capitales de l’Europe”', Téoros [Online], 26(2): 19-26, http:// teoros.revues.org/801.

Castree, N., R. Kitchen and A. Rogers (2013) A Dictionary of Human Geography, Oxford: Oxford University Press.

Bozlağan, R. and M. Daoudov (2008) "Barcelona Reloaded”, The Regional Review, October: 124-125, http://licencetothink.blogspirit.com/list/articles-yaz\%C4\%B1lar/1044530210.pdf

Daoudov, M. (2009a) “New Capital for New Council of Europe”, Today's Zaman, 23 Sept., http://licencetothink.blogspirit.com/list/articles-yaz\%C4\%B1lar/802528680.pdf.

Daoudov, M. (2009b) “Dış Politikada Vize Esnekliğinin Fırsatları”, Birlik Dergisi, 4(July-September): 48-50, http://licencetothink.blogspirit.com/list/articles-yaz\%C4\%B1lar/703329209.pdf.

Daoudov, M. (2013) “Dünyada ve Türkiye’de Uluslararası Göç Alanında Yerel Yönetimlerin Rolü” (Role of Local Governments in Integration Migration in Turkey and in the World), paper presented in at the "Workshop on Migration Management and Harmonization in the Framework of the Law No 6458 on Foreigners and International Protection", organized by the General Directorate of Migration Management of Turkish Ministry of Interior and the International Organization for Migration (IOM), 12 December, Ankara.

Daoudov, M. (2014) “The Role of Local Governments in Integration of Foreigners in Turkey”, Report for International Organization for Migration (IOM), 25 May, http://licencetothink.blogspirit.com/list/ articles-yaz\%C4\%B1lar/34-the-role-of-local-governments-in-integration-of-foreigner.html

Davutoğlu, A. (2015) Press Conference of the Turkish Prime Minister Ahmet Davutoglu on the Preferential Transformation Program under the 10th Development Plan [Video record], 28 January, http:// www.haberler.com/yapisal-donusum-10-kalkinma-plani-6912118-haberi/.

DGMM, Harmonization webpage, webpage of the Directorate General of Migration Management (DGMM) Harmonization page, http://goc.gov.tr/icerik6/about-harmonisation_917_1066_1411_icerik

Ertuna Lagrand, T. (2010) Immigration Law and Policy: the EU Acquis and its Impact on the Turkish Legal Order, Wolf Legal Publishers.

European Commission (2005) "A Common Agenda for Integration: Framework for the Integration of Third-Country Nationals in the European Union", Communication from the Commission to the Council, the European Parliament, the European Economic and Social Committee and the Committee of the Regions, Brussels, 01 September, http://eur-lex.europa.eu/LexUriServ/ LexUriServ.do?uri=COM:2005:0389:FIN:EN:PDF .

European Commission (2011) "European Agenda for the Integration of Third-Country Nationals", Communication from the Commission to the Council, the European Parliament, the European Economic and Social Committee and the Committee of the Regions, Brussels, 20 July, http:// ec.europa.eu/dgs/home-affairs/news/intro/docs/110720/1_en_act_part1_v10.pdf.

E-Visa website, https://www.evisa.gov.tr/en/prerequisites/.

Gatti, E. (2009) “Defining the Expat: the case of high-skilled migrants in Brussels", Brussels Studies, 28(31 
August), www.brusselsstudies.be.

Global Power City Index (GPCI) (2009) Institute for Urban Strategies The Mori Memorial Foundation. http://www.mori-m-foundation.or.jp/english/research/project/6/pdf/GPCI2009_English.pdf

Green L. N. (2009) "Expatriation, Expatriates, and Expats: The American Transformation of a Concept”. The American Historical Review, 114(2): 307-328, http://www.jstor.org/stable/30223780

HSBC Expat Explorer Survey, http://expatexplorer.hsbc.com/survey/\#/country/Switzerland/Turkey.

IFC-Istanbul Project Office (2011) İstanbul Uluslararası Finans Merkezi Proje Ofisi Altyapı Komitesi Arama Konferansları Özet Raporu, Project Office of Istanbul International Financial Center, Infrastructure Committee, Summary Report of the Search Conference, February, http://ifm.ibb.gov.tr/en-US/ Studies/Documents/dokumanlar_dosyalar_/Arama_konferans\%C4\%B1_ozet_raporu_taslak.pdf.

ISTKA (2012) Istanbul Fact Sheet 2012, Istanbul Development Agency (ISTKA) http://www.istka.org.tr/ content/pdf/Istanbul-Fact-Sheet-2012.pdf.

ISTKA (2013) Istanbul Fact Sheet 2013, Istanbul Development Agency (ISTKA) http://www.istka.org.tr/ content/pdf/Fact_Sheet_2013_small.pdf.

ISTKA (2014a) Istanbul Fact Sheet 2014, Istanbul Development Agency (ISTKA). http://www.istka.org.tr/ content/pdf/Istanbul_Fact_Sheet_2014.pdf

ISTKA (2014b) Draft Regional Plan 2014-2023, Istanbul Development Agency (ISTKA). http://www.istka. org.tr/content/pdf/2014-2023-istanbul-Bolge-Plani-n.pdf

ISPAT (a) Economic Outlook page, webiste of Turkish Investment Support and Promotion Agency (ISPAT). http://www.invest.gov.tr/en-US/turkey/factsandfigures/Pages/Economy.aspx

ISPAT (b) Living in Turkey page, website of Turkish Investment Support and Promotion Agency (ISPAT). http://www.invest.gov.tr/en-US/turkey/livinginturkey/Pages/Welcome.aspx

ISPAT (c) Housing page, website of Turkish Investment Support and Promotion Agency (ISPAT). http:// www.invest.gov.tr/en-US/turkey/livinginturkey/Pages/Housing.aspx

IstPat 34. Istanbul Expat \& Public Services Survey (IstPat 34). http://surveymonkey.com/s. aspx?sm=dxrTnDBGXPzOxT\%2bOc7\%2fel5W97y1NKOKtI2Ir7ncY9QQ\%3d

Law 6458, Law on Foreigners and International Protection, No 6458 dated 4 April 2013, http://www.goc.gov. tr/files/files/eng_minikanun_5_son.pdf

Lochak, D. (2006). "Immigration choisie, immigration subie : rien de nouveau sous le soleil?", Ecarts d'identité, 109. http://www.revues-plurielles.org/_uploads/pdf/6_109_2.pdf

Nagel, C. (2005). "Skilled migration in global cities from "other" perspectives", Geoforum, 36: 197-210, http://www.sciencedirect.com/science/article/pii/S0016718504000661

Pérouse, J. F. (2012) "Note sur l'afflux récent des Européens à Istanbul: inerties et recomposition des profils et des positions" Anatoli, 3, La Turquie au carrefour des turbulences migratoires, Paris, CNRS, pp. 41-54, https://www.academia.edu/5583048/Note_sur_1_afflux_r\%C3\%A9cent_des_ Europ\%C3\%A9ens_\%C3\%A0_Istanbul_inerties_et_recomposition_des_profils_et_des_positions

Pérouse, J. F. (2013) "La Turquie face aux soubresauts migratoires dans un contexte de crise", Confluences Méditerranée, 4(87): 85-93, www.cairn.info/revue-confluences-mediterranee-2013-4-page-85.htm

SPO (2009). Strategy and Action Plan for Istanbul International Financial Center (IFC-Istanbul). State Planning Organization, approved by the Resolution of the High Planning Council on 29 September 2009. www.dpt.gov.tr

SPO (2014). 10th Development Plan, 2014-2018, State Planning Organization. http://www.kalkinma.gov.tr/ Lists/Yaynlar/Attachments/628/The\%20Tenth\%20Development\%20Plan\%20\%282014-2018\%29. pdf 